\title{
Gender and age in the language of social media: An easier way to build credibility
}

\author{
A.A.I.N. Marhaeni ${ }^{a^{*}}$, I G W Murjana Yasa ${ }^{a}$ and Mochammad Fahlevi ${ }^{b}$
}

${ }^{\text {a } U n i v e r s i t y ~ o f ~ U d a y a n a, ~ B a l i, ~ I n d o n e s i a ~}$

${ }^{b}$ Management Department, BINUS Online Learning, Bina Nusantara University, Indonesia 11480

\section{H R O N I C L E

$$
\text { A B S T R A C T }
$$

Article history:

Received: June 18, 2021

Received in revised format: June

29, 2021

Accepted: September 6, 2021

Available online: September 9,

2021

Keywords:

Celebrity Trust

Social Media

Credibility

Gender

Age

\begin{abstract}
The use of celebrity endorsements is one of the most popular strategies used by companies today. Celebrities can bring product advantages through advertising and go beyond the complexities of competitive advertising communications. The company invests a large amount of money to get the attention of consumers and gain a competitive position in the market. The purpose of this study is to explore the effect of celebrity trust on the credibility of advertisements, brands, and companies, then the influence between the credibility of advertisements, brands, and companies, and will also explore the role of gender and age as moderating variables. The study used a quantitative method, the sample was taken based on purposive sampling in Jakarta and used the artist with the most followers as the object of research who endorsed food and beverage companies. The results of this study explain that there is a significant influence between celebrity trust on all credibility, gender and age managed to moderate the influence of celebrity trust on credibility. This study provides input to managers and food and beverage companies in using endorsements on Instagram social media as their marketing strategy, especially for companies that have a market share of young people in accordance with the characteristics of the respondents in this study.
\end{abstract}

(C) 2022 by the authors; licensee Growing Science, Canada.

\section{Introduction}

Changes in business strategy that have shifted from offline to online have been able to change the lifestyle of some modern people regarding how they shop and change their lifestyle. Companies are trying to change their strategy to keep up with the changes that occur by doing online marketing which is proven to be more effective (Yoo et al., 2018). All advertisements provided via electronic devices are referred to as digital marketing. When most people hear the term "digital marketing," they immediately think of email, social media, websites, and search engines (Sahir, Sugito, et al., 2021). Nowadays, online product marketing by involving influencers is increasingly being done, given the positive impact it has on increasing business brand awareness. However, so that the results obtained are as expected, businesspeople of course need to be more selective in choosing the right influencers to endorse products. By choosing the right influencers, various goals set, such as increasing brand presence, engagement, and even sales, can actually happen (Fahlevi et al., 2020). Influencers are people who have a large audience on their social media. Usually, what they say, use or use, even what they do, has an influence on the audience and makes these followers imitate or try the products used by influencers. Many people think that influencers should have a lot of followers on social media. In fact, many followers is not a benchmark that makes someone worthy of being an influencer. There are quite a number of influencers with less than hundreds of thousands of followers, but they are able to influence the audience (Sutia et al., 2020). According to Suhaimi (2020) this year is a year full of challenges for the business world due to the outbreak of the corona virus disease. The unpredictable nature of the pandemic has a negative impact on local, national, and global economies. Because of this, governments around the world are stepping up fiscal measures to bridge the economic gap posed by the coronavirus pandemic, especially in small and medium-sized enterprises (SMEs) (Sahir et al., 2021). The * Corresponding author.

E-mail address: marhaeni agung@unud.ac.id (A.A.I.N. Marhaeni)

(C) 2022 by the authors; licensee Growing Science, Canada. doi: $10.5267 /$ j.ijdns.2021.9.007 
SME sector in Malaysia is regarded as the backbone of the Malaysian economy because it generates jobs and economic growth while also assisting the country in lowering its unemployment rate. Furthermore, according to the SME Annual Report, SMEs account for 66.2 percent of overall employment in Malaysia, This clearly demonstrates that the collapse of SMEs as a result of the outbreak will be a significant blow to the country's economy (Sahir, Suginam, et al., 2021). In Wuhan, a different scenario occurred when Lin Qingxuan, a cosmetics company, liquidated 40\% of its storefronts but moved its sales approach to online, using digital platforms like WeChat to contact customers digitally. As a result, its sales increased by 200 percent as compared to the prior year (Suhaimi, 2020). Referring to a survey conducted by JakPat with the theme "Top Endorser in Social Media", this survey was conducted in 2016 on more than 200 respondents and found several new findings regarding the endorsement phenomenon in Indonesia. At the age of 16-25 years, teenagers tend to follow their favourite artists, sports athletes, and online shops. At the age of 26-29 years musician, travellers, and online shop. While at the age of 30-35 years old film artist, music or model, culinary, and parody (Masna, 2016).

There is very little evidence addressing the relationship between celebrity trust and advertising credibility, brand credibility, and corporate credibility in the enormous body of previous literature on the influence of celebrity trustworthiness on views toward advertising, brands, and companies (Singh \& Banerjee, 2018; Susanto \& Setiowati, 2015). The difference between this study and earlier research is that previous research used signaling theory, whereas this study does not. Previous research found that credibility is transferred from one source to another, increasing the credibility and effectiveness of other connected sources (Erdem \& Swait, 2004; Kia, 2016). The effect of celebrity trust on customer gender, according to these data, has gotten little consideration in the literature. Female customers, on the other hand, have been proven to be more impacted by celebrity endorsements than their male counterparts, according to past research. On this basis, it may be concluded that celebrity trust has a bigger impact on advertising credibility, brand credibility, and corporate credibility among female customers than it does among male consumers. Several academics did research and focused on age and gender by Djafarova and Rushworth (2017). Only a tiny number of scholars have looked into the relationship between customer age and celebrity endorsement's influence. The impact of customer age and gender on the effect of celebrity trust on advertising credibility, brand credibility, and corporate credibility has also received minimal attention. Does the celebrity trust factor have any effect on other credibility constructs, specifically based on the consumer's age and gender, in order to close this gap?

The phenomenon of using endorsements on Instagram social media is considered to have a considerable impact on credibility. The experience and expertise of celebrities make their followers on Instagram have great trust in celebrity figures, so many studies that measure the most powerful dimension of endorsement is trust. Previous researchers have conducted research on trust according to the definition of trustworthiness, but further discussion of trust has begun to be studied in depth using the definition of trust which not only measures the cognitive element but also the affective element. The limitation of the problem in this study only discusses endorsements made by artists on Instagram social media. The sector used in this study is the food and beverage company sector, this sector was chosen because there are many endorsements of food and beverage products on Instagram. On the list of 10 artists with the most followers, the five have endorsed food and beverage companies. Based on this, this research will focus on conducting research on food and beverage companies.

\section{Literature Review}

In the discussion of consumer behavior, several previous studies have shown that reliable sources increase consumer attitudes towards advertising and brands, purchase intentions, and price sensitivity (Singh \& Banerjee, 2018). A number of scholars have looked into celebrity trustworthiness in addition to this study on source credibility (Dwivedi \& Johnson, 2013; Wang \& Scheinbaum, 2018). According to their findings, celebrity trustworthiness has a beneficial impact on views about advertising and brands, purchase intentions, brand credibility, company credibility, brand equity, and brand image. Even though the previous researcher (Karanges et al., 2018) has investigated the impact of celebrity trustworthiness on various characteristics using consumer behavior theory. There is minimal evidence of celebrity trust's impact on advertising, brand credibility, or company credibility. This study constructed a conceptual model to evaluate the effect of celebrity trust on the three credibility constructs of advertising, brand, and company using numerous modern marketing theories, particularly those connected to endorsement. Several researchers have grown interested in celebrity trust. Some studies used a model that was similar to celebrity trust (Hussain et al., 2020; Sutia et al., 2020) Its impact on other constructs has been investigated. Several prior studies on celebrity trust have found that it has an impact on a variety of outcomes, including ad effectiveness, brand image, brand awareness, and buy intent. Recent research has discovered that celebrity trust improves advertising attractiveness, social media advertising, brand credibility, brand equity, and brand loyalty (Hussain et al., 2020). Because of this high success rate, a lot of researchers have looked at the effectiveness of celebrity endorsements. They discovered that successful celebrity endorsement advertising necessitates the celebrity being a top figure in the area, the capacity to bring attention to the commercial and the company, and, most significantly, the ability to build trust to both brands and customers (Bergkvist \& Zhou, 2016; Wang \& Scheinbaum, 2018). According to the research, trust and trustworthiness are two distinct constructs with distinct meanings and conceptual features (Soh et al., 2009). The willingness of one party to be vulnerable to the acts of another based on the anticipation that the other will execute particular actions that are significant to the trusting party is defined as trust (Hussain et al., 2020). This concept demonstrates that trust is built on the desire to believe, hope, and take risks. There are two dimensions to trust: cognitive and affective. The logical aspect of human judgment is represented by the cognitive 
dimension. It is one's acquired information or experience that allows one to make confident predictions about the possibility that a partner is competent, accountable, and trustworthy (Franklin \& Marshall, 2019).

The affective dimension denotes the emotional component of human decision-making. It is a person's trust in a partner based on the feelings engendered by reciprocity, care, and concern. (Dadzie et al., 2018). It becomes important when trust is studied in a business-to-consumer context (Terres et al., 2015). Because there is less contractual stability in this situation, a leap of faith from the consumer to the firm becomes critical. When consumers are expected to make high-impact decisions or have little understanding about their purchases, the affective dimension becomes even more important. Well-known personalities, such as celebrity endorsers, might be employed in these instances to elicit empathy and concern for consumers' concerns about purchase decisions, lowering the level of uncertainty (Terres et al., 2015). The attention and care of celebrity endorsers is a significant factor in building trust with consumers and is a key requirement of trust (Dadzie et al., 2018). Trustworthiness, on the other hand, can be defined as honesty, integrity, and a source of trust. It is based on secondary data, such as the entrusting party's attributes or reputation. This demonstrates that beliefs are founded solely on the cognitive level, with the affective dimension being ignored. (Roy et al., 2018). The clear distinction between celebrity trustworthiness and celebrity trust can be illustrated by the fact that the two are significantly different from one another. There are additional differences in terms of the elements that each include a construct. Honesty, reliability, trustworthiness, dependability, and sincerity are all characteristics of celebrity trustworthiness. This differs from the previously mentioned item celebrity trust in that it clarifies that celebrity trustworthiness and celebrity trust are two distinct entities with distinct conceptual meanings and qualities (Akrout \& Diallo, 2017). Celebrity trust has distinct effects on various constructions due to differences in meaning, dimensions, and items (Hussain et al., 2020). Celebrity trust has cognitive and affective dimensions and it is based on the cognitive dimension. Several prior researchers have explained this disparity by stating that celebrity trust and celebrity trustworthiness have different effects. Despite these distinctions, new research indicates that there is little evidence to support the influence of celebrity trust (Akrout \& Diallo, 2017). There is little study on the impact of celebrity trust, particularly on other credibility categories.

\section{Methodology}

This study follows the procedure using quantitative and descriptive research to find out the causal relationship between the constructs in this study, namely celebrity trust, advertising credibility, brand credibility, and company credibility. Data were collected by using a survey method on a questionnaire which was developed based on the measurement of each variable. The development of the questionnaire is based on the operationalization process of variables in which variables are measured based on their definitions and indicators. The sample is part of the population that has the characteristics needed in the study so that the sample must be able to have a representation of the population (Saunders et al., 2009). The sample in this study are followers who live in Jakarta and follow the artist's official account on Instagram, this study wants to measure how much influence celebrity trust has on the credibility of advertisements, brands, and companies as part of marketing a product. this was chosen so that this study was more accurate in measuring the causal effect between variables.

This study is non-probability sampling. This research has the disadvantage that the results may be less representative because of our subjectivity as researchers in choosing the research target sample with the criteria that we made earlier in selecting the right sample to fill out the questionnaire and we used it as data in the analysis. later. The analysis used is only a descriptive analysis, so the conclusions of the study are only to describe the conditions/characteristics of a collection of individuals who are the sample, not to represent the entire population such as the entire population of Jakarta. In addition to the weakness in the form of non-probability sampling, the reason we use this method is because this method has several advantages such as requiring less time, effort and cost than probability sampling, does not require a sample frame in selecting research samples. The most important thing is that there is a target population that has been determined by the researcher, our research focuses on one particular social media platform, namely Instagram to avoid biased answers by respondents who do not use Instagram or do not follow one of the artists who are the object of research. Based on the sampling method we use, non-probability research cannot be generalized to describe the population as a whole. The measurement development in this research refers to the research conducted by Hussain et al. (2020). This study consists of four constructs, namely celebrity trust, advertising credibility, brand credibility, and company credibility. SmartPLS used in this study aims to predict the relationship between constructs, because SmartPLS is different from other SEMs such as CBSEM which can use Amos and Lisrel software which belongs to the parametric group to confirm theory, but SmartPLS can only make predictions, so this is not a drawback. SmartPLS in processing variant-based data, however SmartPLS functions as a complement to research using SEM for research that cannot use CBSEM because it must meet the assumption of normality of data which is quite difficult to do in marketing research with a minimal number of samples.

\section{Result and Discussion}

Before analysing the path model and hypothesis testing, the validity of each indication is evaluated using the Smart PLS 3 program at the following stage. According to the rule of thumb Hair et al. (2011), the outer loading should have a value of more than 0.7 , but for models that are still relatively new, the outer loading of 0.6 is still accepted to pass the validity test (Ghozali, 2018). 


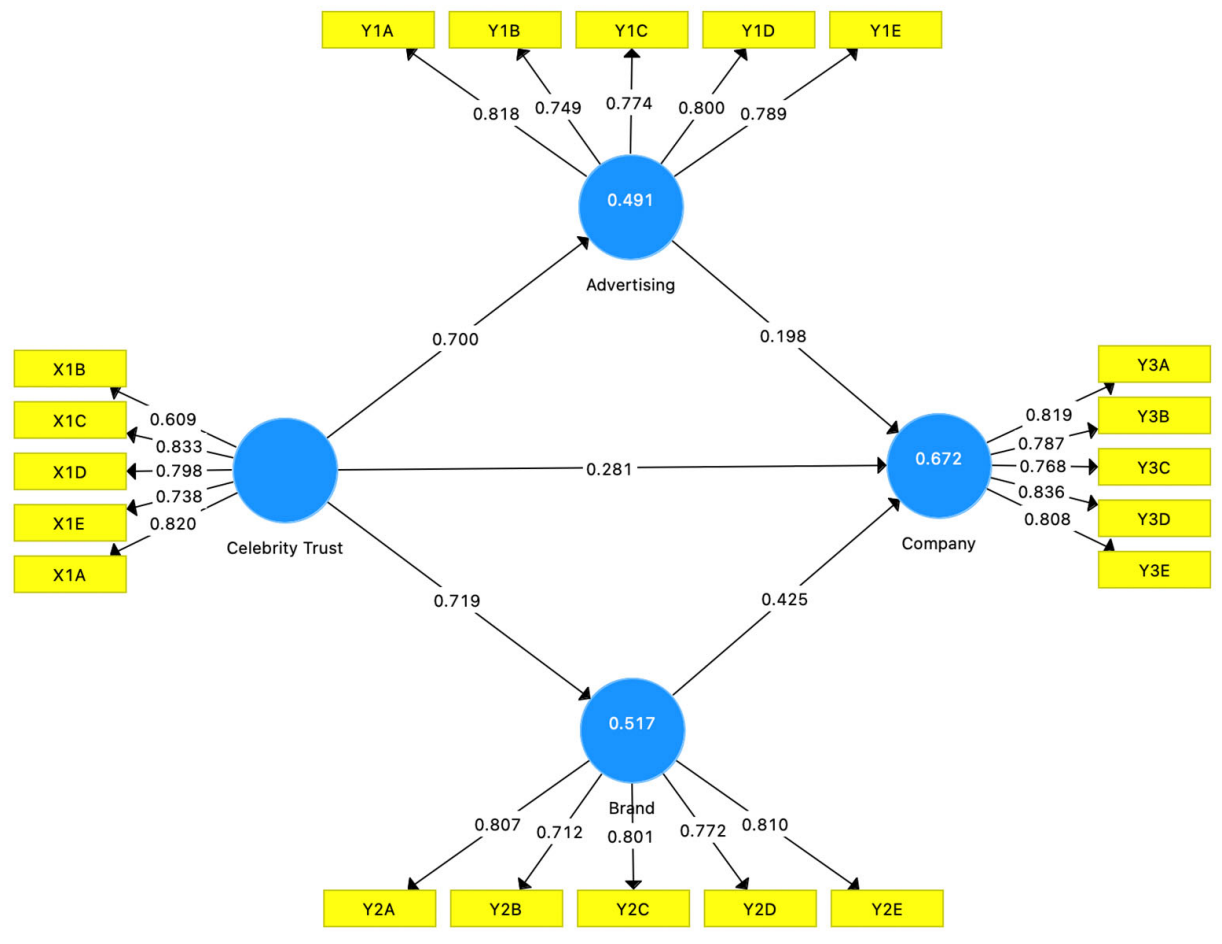

Fig. 1. Full Model SEM

All the data above shows that all items have an outer loading value above 0.6 so that it has passed the validity test. In the new model, all items from celebrity trust are in accordance with the items that meet the minimum outer loading, which is above 0.7 so that each item can reflect each construct. The results of this validity test explain that all items have passed the validity test and can be continued on the reliability test.

Table 1

Reliability Test

\begin{tabular}{cccc}
\hline & Cronbach's Alpha & rho_A & $\begin{array}{c}\text { Composite Reliability } \\
\text { tracted (AVE) }\end{array}$ \\
\hline Advertising & 0.846 & 0.852 & 0.890 \\
Brand & 0.840 & 0.843 & 0.886 \\
Celebrity Trust & 0.819 & 0.833 & 0.874 \\
Company & 0.863 & 0.867 & 0.910 \\
\hline
\end{tabular}

In the data it is known that the value of Cronbach' alpha, rho-A, and composite reliability has a value greater than 0.7 (Hair et al., 2011), so it can be concluded that all constructs have passed the reliability test or can be said to be reliable. The Average Variance Extracted (AVE) number is another metric. The AVE value is a measure of the variation or diversity of manifest variables that the latent construct can own. As a result, the more the variation or diversity of manifest variables that the latent construct can include, the greater the manifest variable's representation on the latent construct. Ghozali (2018) proposes AVE as a criterion for determining convergent validity. A useful metric of convergent validity is an AVE value of at least 0.5 . That is, the latent variable can account for more than half of the variance in the indicators on average. The sum of the squares of the loading factor divided by the mistake yields the AVE value. The AVE measure can also be used to assess the reliability of a latent variable's component score, with findings that are more conservative than composite reliability (CR). The AVE value will be the same as the average value of block communalities if all indicators are normalized. Based on the information in the table above, all latent constructs have an AVE value greater than 0.5, indicating that they are reliable.

Table 2

Model Summary

\begin{tabular}{lll}
\hline & R Square & R Square Adjusted \\
\hline Advertising & 0.491 & 0.488 \\
Brand & 0.517 & 0.514 \\
Company & 0.672 & 0.666 \\
\hline
\end{tabular}


Based on the table above, it is known that the R Square of advertising credibility is 0.491 or $49,1 \%$, it can be interpreted that celebrity trust can explain the credibility of advertising by $48.8 \%$. The brand credibility variable has a value of 0.517 or $51.7 \%$, it can be interpreted that celebrity trust can explain the credibility of the brand by $51.7 \%$. The company's credibility variable has a value of 0.672 or $67.2 \%$, it can be interpreted that celebrity trust, advertising credibility, and brand credibility can explain the company's credibility by $67.2 \%$. The path analysis value was employed in this study to assess the hypothesis for each direct effect path.

Table 3

Fit Summary

\begin{tabular}{lll}
\hline & Saturated Model & Estimated Model \\
\hline SRMR & 0.081 & 0.094 \\
d_ULS & 1.326 & 1.867 \\
d_G & 0.550 & 0.603 \\
Chi-Square & 525.645 & 549.003 \\
NFI & 0.913 & 0.924 \\
\hline
\end{tabular}

In the estimation of the match index table above, it is known that SRMR and NFI are known, the table gives the approximate results of the PLS-SEM model or the value of this criterion has met the SRMR threshold $<0.08$ and NFI $>0.90$ ). SRMR is defined as the difference between the observed correlation and the implied correlation matrix of the model. Thus, it is possible to assess the mean magnitude of the difference between the observed correlation and the expected correlation as an absolute measure of the fit criterion (model). The value must be less than 0.10 or 0.08 then the model is considered suitable. Hair et al. (2011) introduces SRMR as a measure of goodness of fit for PLS-SEM which can be used to avoid model specification errors. The path diagram for hypothesis testing is depicted in the image below:

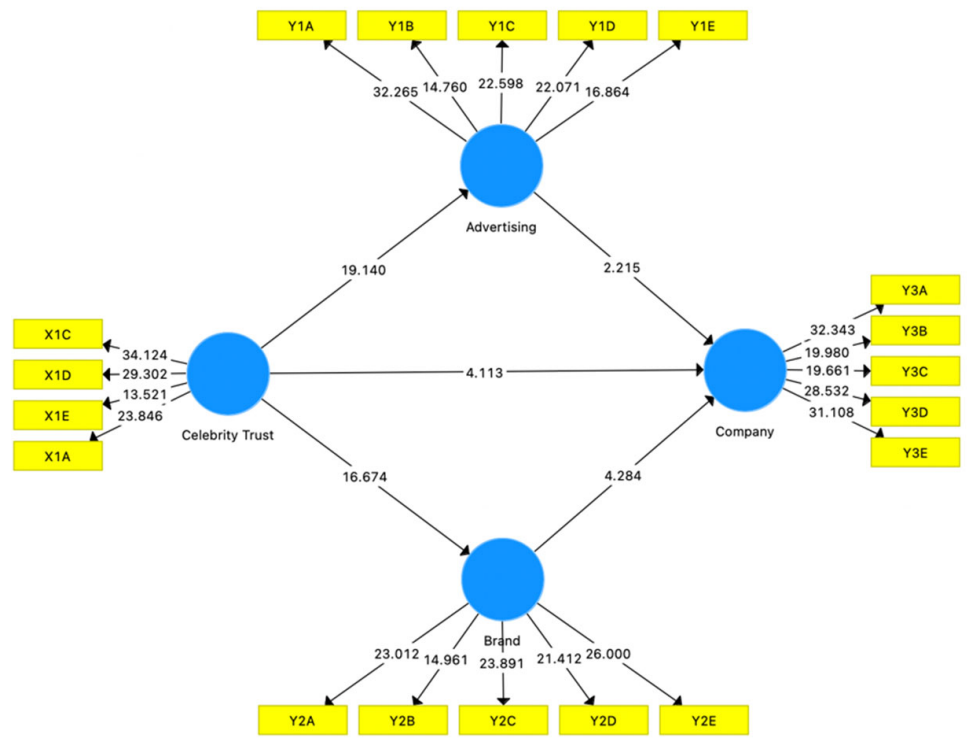

Fig. 2. Path Analysis

According to Fig. 2, it is known that each item has a coefficient value on its construct greater than 1.96 so it can be said that the item can measure each construct in this model.

Table 4

Bootstrapping

\begin{tabular}{|c|c|c|c|c|c|}
\hline & Original Sample (O) & Sample Mean (M) & $\begin{array}{l}\text { Standard Devia- } \\
\text { tion (STDEV) }\end{array}$ & $\begin{array}{l}\text { T Statistics } \\
(|\mathrm{O} / \mathrm{STDEV}|)\end{array}$ & P Values \\
\hline Advertising $\rightarrow$ Company & 0.198 & 0.195 & 0.083 & 2.384 & 0.018 \\
\hline Brand $\rightarrow$ Company & 0.425 & 0.422 & 0.095 & 4.463 & 0.000 \\
\hline Trust $\rightarrow$ Advertising & 0.700 & 0.705 & 0.039 & 17.838 & 0.000 \\
\hline Trust $\rightarrow$ Brand & 0.719 & 0.723 & 0.047 & 15.338 & 0.000 \\
\hline Trust $\rightarrow$ Company & 0.281 & 0.289 & 0.073 & 3.870 & 0.000 \\
\hline
\end{tabular}


In Table 4, it is known that celebrity trust has a positive influence on the credibility of advertisements with a $\mathrm{T}$ statistic of 17.838 and a $\mathrm{P}$ Value of 0.000 , so it can be said that the effect is significant and the hypothesis is accepted. Celebrity trust has a positive effect on brand credibility with a T statistic of 15.338 and a $\mathrm{P}$ Value of 0.000 , so it can be said that the effect is significant and the hypothesis is accepted. Celebrity trust has a positive influence on the credibility of the company with a $\mathrm{T}$ statistic of 3.870 and a P Value of 0.000 , so it can be said that the effect is significant and the hypothesis is accepted. Advertising credibility has a positive influence on the credibility of the company with a T statistic of 2.384 and a P Value of 0.018 , it can be said that the effect is significant, and the hypothesis is accepted. Brand credibility has a positive influence on the credibility of the company with a T statistic of 4.463 and a P Value of 0.000 , it can be said that the effect is significant and the hypothesis is accepted. Celebrity Trust, the results of this study explain that the influence of celebrity on social media, especially Instagram has an effective way for companies, so that companies engaged in the food and beverage industry, especially those with a market share of young people can use marketing on social media such as doing endorsements with celebrity which has the most followers and has good trust in the community in Jakarta. The findings of this study have a lot of consequences for managers and businesses. Based on cognitive and emotive measurements, these findings aid managers in comprehending the complicated phenomena of celebrity trust. This study can assist them in hiring celebrities based on the combined influence of their character and emotional attributes, which is significant in this study. Consumers use both the cognitive and affective dimensions when deciding whether to trust a celebrity's recommendation. They give celebrity supporters a grade based on their trustworthiness and the goodwill they generate through their endorsements. Marketers can use this phenomenon by recruiting celebrity supporters based on an understanding of the importance of these two dimensions. Advertising Credibility, the credibility of the company's advertisements is important for the company, especially when the advertisement is displayed on Instagram social media, it is proven that the credibility of the advertisement can increase the credibility of the brand and the credibility of the company. Managers who seek to understand the impact of celebrity trust on advertising believability will benefit from this research. Managers can grasp how significant a highly trusted celebrity is in generating advertising credibility based on the findings of this study. Celebrities with a high level of trust can benefit from advertising, whilst celebrities with a poor level of trust can harm the construct or its linked businesses.

Brand Credibility: The conclusion in this study explains that brand credibility also increases the credibility of the company so that marketing through Instagram for a company's brand will directly affect the company, this is because the brand is important, especially for the lives of people who live in Jakarta. Additionally, this research aids managers in comprehending the impact of advertising credibility on brand and business credibility, as well as the impact of brand credibility on company credibility. This aids managers in comprehending the significant impact that one credibility construct might have on the others. This study also aids managers in making advertising, marketing, and company decisions based on the importance and trustworthiness of each relationship. Marketers will be able to comprehend the significance of connected relationships based on these findings, as well as study how one construct might boost or diminish the credibility of the others.

Company Credibility: The credibility of the company in this study is concluded to be influenced by many things, both celebrity trust, advertising credibility, and brand credibility, so that companies engaged in the food sector can increase company credibility through Instagram social media because it is proven to be very effective for consumers, especially for consumers in Jakarta. The contribution of the theoretical model has been proven by the confirmation of most of the direct impacts. It has also been confirmed that celebrity trust may be exploited as marketing and can boost the credibility of linked constructions. Advertising and brand credibility have also been demonstrated to have a favorable direct effect on other connected variables that will have an impact on the organization. The findings above are the direct influence between variables in this study, the moderating effect of each of these relationships will also be analyzed whether gender and age have an influence in moderating causal relationships between variables in this study, so the model below explains the moderating role of gender and age.

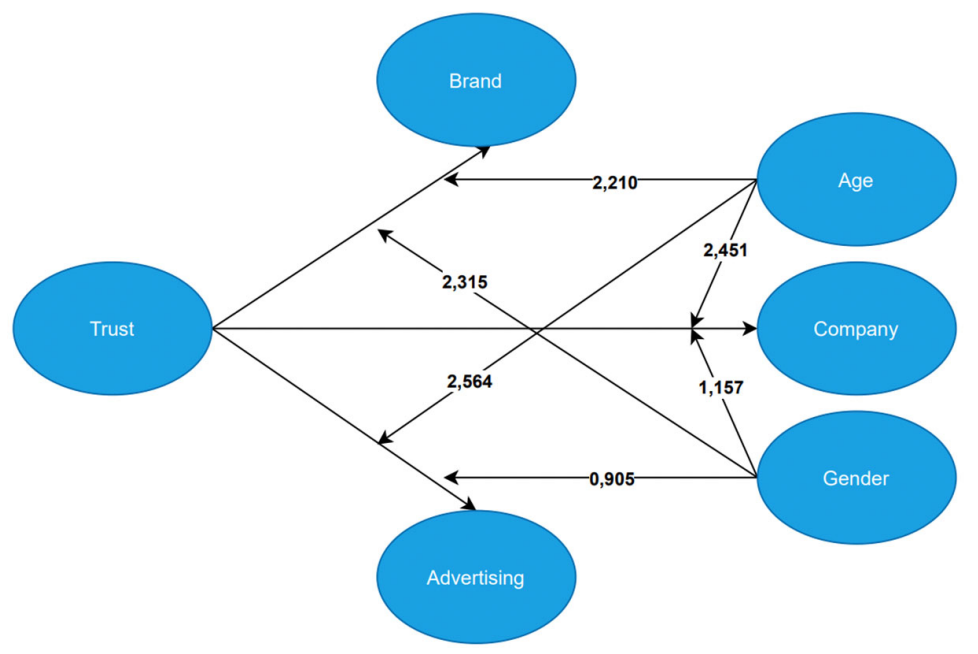

Fig. 3. Moderation Model 
Based on a structural model with a moderating construct that has been added to the model, the results of bootstrapping in this model after being influenced by the moderating role of gender and age are described in the table below.

Table 5

Path Coefficients Moderation

\begin{tabular}{lcc}
\hline \multicolumn{1}{c}{ Hypothesis } & Coefficients & \\
\hline Gender - Trust $\rightarrow$ Brand & 2.315 & 0.020 \\
Gender - Trust $\rightarrow$ Advertising & 0.905 & 0.984 \\
Gender - Trust $\rightarrow$ Company & 1.157 & 0.678 \\
Age - Trust $\rightarrow$ Brand & 2.210 & 0.028 \\
Age - Trust $\rightarrow$ Advertising & 2.564 & 0.010 \\
Age - Trust $\rightarrow$ Company & 2.451 & 0.014 \\
\hline
\end{tabular}

Gender moderation has a significant effect so that companies need to divide their market share and their advertisements are aimed at one gender because in some studies companies that are gender-inclusive are also more in demand by consumers. The moderating effect of gender was confirmed, which suggests that the theoretical model can support the role of moderating factors in the effect of celebrity trust on other credibility constructs. Age moderation in this study is that age has an effect on the constructs in this study, so companies, especially food companies, need to carry out strategies at a certain age in marketing and increasing the company's credibility on Instagram. The age difference also has influence in moderating the relationship so that the age factor for managers can be used as a special strategy in building credibility on Instagram in making endorsements. These results are in accordance with research conducted by (Peetz et al., 2004) who conducted a related study in which they asked consumers to identify celebrities. They found that male participants were four times more likely than female participants to correctly identify all supporters. They also found that male endorsers were more influential than their female counterparts. These findings suggest that the effect of celebrity trust based on consumer gender has received little attention in the literature. However, based on previous findings, female consumers have been found to be more influenced by celebrity endorsements than their male counterparts. Based on this, it can be said that the influence of celebrity trust on advertising credibility, brand credibility and company credibility is greater among female consumers than among male consumers. This difference is because in this study only discusses celebrity trusts who endorse on Instagram, while previous studies do research in general on each form of endorsement, the difference is also due to differences in demographics and different consumer purchasing power between the US and Indonesia. These results are not in accordance with the research conducted by (Hussain et al., 2020) that in his research find the effect of the moderating variable age in strengthening the influence of celebrity trust on the credibility of advertisements, brands, and companies. Although similar studies are very rare before, several researchers conducted research and focused on age by (Djafarova \& Rushworth, 2017) Regarding the relationship between consumer age and the influence of celebrity endorsement, only a small number of researchers have examined this. There has also been little focus on the impact of consumer age on the effect of celebrity trust on advertising credibility, brand credibility and company credibility. To minimize this gap, does the celebrity trust factor have any effect on other credibility constructs, especially based on the age of the consumer.

\section{Conclusion}

The results of this study have implications for companies in Indonesia in doing marketing, especially on social media such as on Instagram, that using the right celebrity will clearly increase the credibility of advertisements, brands, and companies. Trust in celebrities is able to attract consumers to increase the company's credibility in the eyes of consumers, especially for the consumer market who has an Instagram account and follows trustworthy celebrities. Companies can take advantage of the increasing number of Instagram users in Indonesia every year and become a lifestyle, especially for young people in Indonesia. In the phenomenon in Indonesia, the food and beverage industry grew quite significantly, not only in the offline realm but also in online sales. Because of the Covid-19 pandemic, the Jakarta Regional Government carried out social restrictions on a large scale, making the food and beverage industry that operates offline severely affected their sales. The shift in consumer behavior that prefers to keep their distance and reduce interactions when transacting makes entrepreneurs in the food and beverage sector change their business strategies for expansion in the online world, one of which is social media such as Instagram. It is known that the research above uses the majority dominated by young people aged 20-30 years who often use Instagram in their lives. Searches for food and beverage information are also carried out on Instagram, therefore currently many banners or advertisements elsewhere include their Instagram usernames in advertisements so that consumers can follow their official accounts on Instagram. The growth in endorsement requests has also increased, this is because advertising on social media has proven to be more effective in current conditions. Jakartans prefer to choose their food at home and have more time to see and make their choice based on reviews or reviews given by influencers.

\section{References}

Akrout, H., \& Diallo, M. F. (2017). Fundamental transformations of trust and its drivers: A multi-stage approach of businessto-business relationships. Industrial Marketing Management, 66, 159-171. 
Bergkvist, L., \& Zhou, K. Q. (2016). Celebrity endorsements: A literature review and research agenda. International Journal of Advertising, 35(4), 642-663.

Dadzie, K. Q., Dadzie, C. A., \& Williams, A. J. (2018). Trust and duration of buyer-seller relationship in emerging markets. Journal of Business \& Industrial Marketing.

Djafarova, E., \& Rushworth, C. (2017). Exploring the credibility of online celebrities' Instagram profiles in influencing the purchase decisions of young female users. Computers in Human Behavior, 68, 1-7.

Dwivedi, A., \& Johnson, L. W. (2013). Trust-commitment as a mediator of the celebrity endorser-brand equity relationship in a service context. Australasian Marketing Journal (AMJ), 21(1), 36-42.

Erdem, T., \& Swait, J. (2004). Brand credibility, brand consideration, and choice. Journal of Consumer Research, 31(1), 191198.

Fahlevi, M., Rabiah, A. S., Pradipta, I. A., \& Marta, A. (2020). Tourism and Absorption of The Labor Force in Indonesia: A Strategy for Development. 16001, 2-6.

Franklin, D., \& Marshall, R. (2019). Adding co-creation as an antecedent condition leading to trust in business-to-business relationships. Industrial Marketing Management, 77(September 2018), 170-181. https://doi.org/10.1016/j.indmarman.2018.10.002

Ghozali, I. (2018). Aplikasi Analisis Multivariate dengan Program IBM SPSS 25. (Edisi 9). Semarang: Badan Penerbit Universitas Diponegoro.

Hair, J. F., Ringle, C. M., \& Sarstedt, M. (2011). PLS-SEM : Indeed a Silver Bullet PLS-SEM : Indeed a Silver Bullet. Journal of Marketing Theory and Practice, 19(2), 139-152. https://doi.org/10.2753/MTP1069-6679190202

Hussain, S., Melewar, T. C., Priporas, C. V., Foroudi, P., \& Dennis, C. (2020). Examining the effects of celebrity trust on advertising credibility, brand credibility and corporate credibility. Journal of Business Research, 109(November 2019), 472-488. https://doi.org/10.1016/j.jbusres.2019.11.079

Karanges, E., Johnston, K. A., Lings, I., \& Beatson, A. T. (2018). Brand signalling: An antecedent of employee brand understanding. Journal of Brand Management, 25(3), 235-249.

Kia, F. T. (2016). Brand Credibility and Brand Prestige on Influencing Purchase a Mobile Brand. The Social Sciences, 11(9), 2200-2205.

Masna, A. (2016). Facebook and Instagram Rule Indonesia Social Media but 75\% Use Path Daily. AdDiction.

Peetz, T. B., Parks, J. B., \& Spencer, N. E. (2004). Sport Heroes as Sport Product Endorsers: The Role of Gender in the Transfer of Meaning Process for Selected Undergraduate Students. Sport Marketing Quarterly, 13(3).

Roy, S. K., Balaji, M. S., Soutar, G., Lassar, W. M., \& Roy, R. (2018). Customer engagement behavior in individualistic and collectivistic markets. Journal of Business Research, 86(October 2016), 281-290. https://doi.org/10.1016/j.jbusres.2017.06.001

Sahir, S., Fahlevi, M., Kasbuntoro, K., \& Sutia, S. (2021). Effect of halal food management system certification on buying interest of Indonesian consumer goods. Uncertain Supply Chain Management, 9(3), 731-738.

Sahir, S. H., Suginam, S., \& Fahlevi, M. (2021). Online Travel Agency Marketing Strategy: Implications For Consumer Repurchase Decision. EKUITAS (Jurnal Ekonomi Dan Keuangan), 5(2).

Sahir, S. H., Sugito, S., Hasibuan, A., \& Fahlevi, M. (2021). Customer Experience Management: The Online Travel Agencies in Indonesia. ICIC Express Letters Part B: Applications, 12(4), 369-375.

Saunders, M., Lewis, P., \& Thornhill, A. (2009). Research Methods for Business Students (5th ed.). Prentice Hall.

Singh, R. P., \& Banerjee, N. (2018). Exploring the Influence of Celebrity Credibility on Brand Attitude, Advertisement Attitude and Purchase Intention. Global Business Review, 19(6), 1622-1639. https://doi.org/10.1177/0972150918794974

Soh, H., Reid, L. N., \& King, K. W. (2009). Measuring trust in advertising. Journal of Advertising, 38(2), 83-104.

Suhaimi, N. (2020). Shifting businesses from offline to online. Emirresearch. https://www.emirresearch.com/shifting-businesses-from-offline-to-online/

Susanto, M., \& Setiowati, R. (2015). Celebrity endorsement, brand credibility and brand equity of smartphone in Jakarta. International Business Management, 9(3), 221-231.

Sutia, S., Fahlevi, M., Rita, Rabiah, A. S., \& Adha, S. (2020). The Influence of Endorsement on Instagram toward Customer Behavior. International Journal of Psychosocial Rehabilitation, 24(08), 6628-6634. https://doi.org/10.37200/IJPR/V24I8/PR280685

Terres, da S., Santos, M. dos, Pizzutti, C., Basso, \& Kenny. (2015). Antecedents of the client's trust in low-versus highconsequence decisions. Journal of Services Marketing.

Wang, S. W., \& Scheinbaum, A. C. (2018). Enhancing brand credibility via celebrity endorsement: Trustworthiness trumps attractiveness and expertise. Journal of Advertising Research, 58(1), 16-32.

Yoo, J., Lee, H., \& Jin, Y. (2018). Effects of Celebrity Credibility on Country's Reputation: A Comparison of an Olympic Star and a Political Leader. Corporate Reputation Review, 21(3), 127-136. https://doi.org/10.1057/s41299-018-0048-5

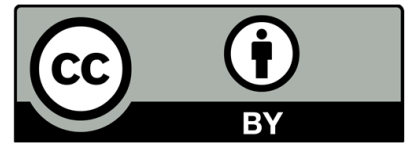

(C) 2022 by the authors; licensee Growing Science, Canada. This is an open access article distributed under the terms and conditions of the Creative Commons Attribution (CC-BY) license (http://creativecommons.org/licenses/by/4.0/). 